\title{
Sosyal Bilgiler Eğitimi Lisans ve Lisansüstü Programlarında Eleştirel Düşünme Becerileri
}

Critical Thinking Skills in Graduate and Undergraduate Social Studies Education Programs

\author{
Ahmet Galip YÜCEL ${ }^{1}$ \\ ${ }^{1}$ Araştırma Görevlisi, Nevşehir Hacı Bektaş Veli Üniversitesi, Sosyal Bilgiler Eğitimi Anabilim Dalı, \\ ahmetyucel@nevsehir.edu.tr, (DD0000-0001-9435-7315
}

\begin{tabular}{l} 
Araştırma makalesi/ Research Article \\
Geliş: 2021-10-14 \\
\hline Atıf/ Citation \\
Yücel, A. G. (2021). Sosyal bilgiler eğitimi lisans ve lisansüstü programlarında eleştirel düşünme \\
becerileri. Maarif Mektepleri Uluslararası Eğitim Bilimleri Dergisi, 5(2), 224-236. \\
https://doi.org/10.46762/mamulebd.1009721 \\
Yücel, A. G. (2021). Critical thinking skills in graduate and undergraduate social studies education \\
programs. Maarif Mektepleri International Journal of Educational Sciences, 5(2), 224-236. \\
https://doi.org/10.46762/mamulebd.1009721
\end{tabular}

Öz

Milli Eğitim Bakanlığınca 2018 yılında hazırlanan öğretim programlarında yer alan yetkinlikler ile sosyal bilgiler öğretim programında yer alan temel becerilerin kaynağı Türkiye Yeterlikler Çerçevesidir. Öğretim programlarının temel amaçlarının başında bu yetkinlik ve becerilere sahip bireyler yetiştirmek gelmektedir. Sosyal Bilgiler Dersi Öğretim Programının özel amaçlarında ise öğrencilerin doğru ve güvenilir bilgiye ulaşma yollarını bilmelerinin ve eleştirel düşünmelerinin amaçlandığı ifade edilmektedir. Ayrıca yine programda öğrencilere kazandırılacak beceriler arasında eleştirel düşünme ve karar verme gibi bilişsel becerilere yer verilmiştir. $\mathrm{Bu}$ becerileri öğrencilerin kazanması sosyal bilgiler öğretmenlerinin, öğretmenlerin kazanması ise sosyal bilgiler öğretmen eğitimcilerinin kazanması ile mümkün olabilir. Bu bağlamda sosyal bilgiler lisans programları ile bilim uzmanı ve bilim doktoru yetiştirmeyi amaçlayan sosyal bilgiler lisansüstü programlarından beklenen, öğrencilerde sosyal bilgiler programındaki becerilere yönelik gelişmiş bir anlayış geliştirmeleridir. $\mathrm{Bu}$ nedenle çalışmada, sosyal bilgiler lisans ve lisansüstü programlarında eleştirel düşünme becerilerinin öğretimine ne düzeyde yer verildiğinin incelenmesi amaçlanmıştır. Bu amaca yönelik olarak Sosyal Bilgiler Öğretmenliği Lisans Programı ve Türkiye' de lisansüstü düzeyde 
yürütülen sosyal bilgiler eğitimi programları doküman incelemesi yoluyla analiz edilmiştir. Lisans programında, doğrudan düşünme becerilerine odaklanan zorunlu bir ders olmadığı, sadece meslek bilgisi seçmeli bir derse programda yer verildiği, lisansüstü programlarda ise düşünme becerilerine odaklanan ders sayısının yetersiz olduğu anlaşılmıştır. Bu bağlamda çalışma sonucunda incelenen programlarda eleştirel düşünme başta olmak üzere düşünme becerilerinin görmezden gelindiği sonucuna ulaşılmıştır.

Anahtar Kelimeler: Sosyal bilgiler eğitimi, eleştirel düşünme, düşünme becerileri

\section{Abstract}

The source of the competencies in the curriculums prepared by the Ministry of National Education in 2018 and the basic skills in the social studies curriculum is the Turkish Competencies Framework. One of the main aims of the curriculum is to raise individuals with these competencies and skills. In the special aims of the Social Studies Curriculum, it is stated that it is aimed for students to know the ways to reach accurate and reliable information and to think critically. In addition, cognitive skills such as critical thinking and decision making were included among the skills to be acquired by the students in the program. It may be possible for students to acquire these skills if teachers these thinking skills and it may be possible for teachers to acquire these skills if social studies teacher educators have these skills. In this context, what is expected from social studies undergraduate programs and social studies graduate programs aiming to train master and doctorate students is that students develop an advanced understanding of the skills in the social studies program. For this reason, it is aimed to examine to what extent critical thinking skills courses are there in social studies undergraduate and graduate programs. For this purpose, Social Studies Education Undergraduate Program and social studies education programs carried out at postgraduate level in Turkey were analyzed through document analysis. It has been understood that there is no compulsory course focusing on thinking skills in the undergraduate program, only an elective course is included in the program, and the number of courses focusing on thinking skills in graduate programs is extremely insufficient. In this context, because of the study, it was concluded that thinking skills, especially critical thinking, were ignored in the programs examined.

Keywords: Social studies, critical thinking, thinking skills

\section{Giriş}

Sosyal ve ekonomik yapının, baş döndüren bir hızla gelişen bilim ve teknolojiyle karşılıklı etkileşimi, birkaç yıllık bir süre içinde dahi insanı daha önce hiç deneyimlemediği yeni sorunlarla karşı karşıya bırakmaktadır. Söz konusu değişim ve dönüşümlerin bir parçası olarak iletişim teknolojilerinin toplumun her kesiminde yaygın bir biçimde kullanılması, her kesimden insanın bu iletişim araçları ile kendilerini ifade etme çabasına girişmesi ve tarihin hiçbir döneminde üretilmediği kadar fazla bilginin dolaşıma sokulması da sorunları derinleştiren unsurların başında gelmektedir. Hızlı değişim ve dönüşümler ile bunların sonucunda açığa çıkan yeni sorunlar dünyayı, günden güne anlaşılması ve yaşanması daha zor olan bir yer haline getirmektedir. Bu bağlam içinde insanlar birçok konuda karar ve sorumluluk alma zorunluluğuyla karşı karşıyadır. Çağdaş toplumlarda vatandaşlar toplum açısından önem arz eden kararlar almaktadırlar. Bireyler; demokratik katılım, sosyal sorumluluk, sivil toplum kuruluşları ile siyasi partilere katılma ve siyaset yapma gibi 
toplumu ilgilendiren birçok konuda karar almakta ve içinde yaşadıkları toplum ile vatandaşı oldukları devlete çeşitli araçlarla yön vermektedir. Bireylerin verdikleri kararların kapsamı sadece toplumlarıyla sınırlı değildir, insanların para ve güç peşindeki mücadeleleri geçmişte olduğu gibi bugün de, şekil değiştirerek, varlığını sürdürmektedir. Bireylerin sahip olacakları yaşam koşullarının kalitesini sadece sahip oldukları nitelikler değil, kendileri hakkında verdikleri kararların isabeti de belirlemektedir.

Her gün önemli birçok konuda, sonuçlarının sorumluluğunu üstlenmek kaydıyla karar vermek günümüz insanının yüzleştiği ciddi bir mücadeledir. Dolayısıyla günümüzde isabetli, yerinde ve iyi düşünülmüş kararlar verebilmek önemli ve bireylerden beklenen bir beceri haline gelmiştir. Paul ve Elder'e (2002) göre, insanlar düşünürken hata yapmaya eğilimlidir. Düşünmedeki yetersizlikler ve hatalar bireyin hayat kalitesine ve ekonomik durumuna olduğu kadar (Paul ve Elder, 2002), toplumun refahına da olumsuz yönde etki etmektedir. Halpern (2002) bu bağlam karşısında, günümüz insanının dünün insanına göre daha eğitimli olması gerektiğini ileri sürmektedir. Çünkü her anlamda değişen ve karmaşık bir hale gelen sorunlar üzerinde iyi ve akıllıca düşünülmediği takdirde ulaşlabilecek birçok çözüm kap1 dışında bırakılmış olacaktır. Bu bağlamda düşünmedeki yetersizliklerin ve hatalarının giderilerek düşünmenin nitelikli hale getirilmesinin temel yolu öğrencilerin eleştirel düşünme becerilerini kazanmalarının sağlanmasıdır (Paul ve Elder, 2002). Çünkü eleştirel düşünme farklı bağlamlarda mevcut delil ve bilgilere dayanarak bağlama duyarlı ve isabetli karar vermek için gereken bilişsel becerileri kapsar. Bu nedenle eleştirel düşünmenin öğretilmesi gerek birey gerekse toplum lehine bir yaklaşımdır.

Ennis'e (1985) göre eleştirel düşünme, inanma ya da eyleme geçme hususunda karar almaya odaklanan yansıtıcı, mantıklı düşünme biçimidir. Lipman'a (1987) göre ise eleştirel düşünme analiz etme, değerlendirme, varsayımda bulunma, açıklama yapma gibi bilişsel faaliyetleri içeren, ölçüte dayanan, içeriği göz önünde bulunduran ve öz düzenleme gerektiren bir düşünme türüdür. Benzer bir açıklama öne süren Delphi raporunu yazıya döken Facione ve Facione $(2015 ; 1996)$ ise eleştirel düşünmeyi yorumlamayı, analiz etmeyi, değerlendirme yapmayı ve çıkarımda bulunmayı gerektiren bir karar verme eylemi olarak tanımlamaktadır.

Türkiye'de düşünme öğretimi ortaokullarda öncelikli olarak sosyal bilgiler derslerine bırakılmıştır. Eleştirel düşünme 2018 yılında uygulamaya konulan sosyal bilgiler programında sayılan becerilerden biridir (MEB, 2018). Öğretim programların perspektifi başlıklı kısımda bilgi, beceri ve davranışların değer ve yetkinlikleri öğrencinin hayata aktarmasının yolu olduğu belirtilmiştir. Bunun yanında öğretim programlarında öğrencinin aktifliği ön planda olup öğrencinin bilgiyi keşfetmesi ve öğrenme sürecini kendisinin kontrol etmesi beklenmektedir (Durmaz ve Kiriş Avaroğulları, 2016). Sosyal Bilgiler Dersi Öğretim Programının Özel Amaçları kısmında ise eleştirel düşünmeye doğrudan yer verilerek öğrencilerin eleştirel düşünme becerilerine sahip olmasının amaçlandığı belirtilmiştir. Programın diğer özel amaçlarında da eleştirel düşünmeyi gerektiren çeşitli ifadeler bulunmaktadır. Bu 
bilgilere dayanarak eleştirel düşünmenin, vatandaş yetiştirme sürecinde önemli bir beceri olarak görüldüğü söylenebilir. Bu kapsamda sosyal bilgiler derslerini yürütecek öğretmenlerin ve bu öğretmenleri yetiştirecek öğretmen eğitimcilerinin eleştirel düşünme beceri ve eğilimlerine sahip olmaları ve düşünme alanında derin bir anlayış geliştirmiş olmaları önem kazanmaktadır. Bu sayılanları sağlamak ise programlarda düşünme becerilerini konu edinen derslere yer vermekle mümkün olabilir. Bu durum göz önünde bulundurulduğunda sosyal bilgiler lisans ve lisansüstü programlarında eleştirel düşünme becerilerine ne düzeyde yer verildiğinin incelenmesi önemli bulunmuştur. $\mathrm{Bu}$ kapsamda çalışmada, sosyal bilgiler lisans ve lisansüstü programlarında yürütülen dersler ile ders içerikleri incelenmiştir.

\section{Araştırmanın Amacı}

$\mathrm{Bu}$ araştırma ile eleştirel düşünme başta olmak üzere düşünme becerilerini ele alan derslere, sosyal bilgiler öğretmenliği lisans programında ve lisansüstü sosyal bilgiler eğitimi programlarında ne düzeyde yer verildiğinin belirlenmesi amaçlanmıştır. Bu bağlamda aşağıdaki sorulara yanıt aranmıştır:

1. Sosyal bilgiler eğitimi lisansüstü programlarında düşünme becerilerine ne düzeyde yer verilmektedir?

2. Sosyal bilgiler eğitimi lisans programında düşünme becerilerine ne düzeyde yer verilmektedir?

\section{Sinurlılıklar}

Bu çalışma Türkiye'de bulunan devlet ve vakıf üniversitelerinin internet sitelerinde 01/10/2021 - 11/10/2021 tarihleri arasında yaymlanan mevcut AKTS bilgi paketleri ve ders katalogları ile 2018 yılında uygulamaya konulan Sosyal Bilgiler Öğretmenliği Lisans Programı ile sinırlıdır.

\section{Yöntem}

Sosyal bilgiler yüksek lisans ve doktora programlarında eleştirel düşünme becerilerinin mevcut durumunu incelemeyi amaçlayan bu araştırma nitel araştırma yöntemi desenlerinden durum çalışmasına uygun olarak tasarlanmıştır. Durum çalışması ile gerçek yaşamın ve mevcut ortamın içindeki durumlar incelenir (Yin, 2009). Durum çalışmaları, bir durumu betimler ya da durum temalarını ortaya koyar (Creswell, 2013).

Bu bağlamda çalışma kapsamında lisans ve lisansüstü düzeylerinden yürütülen sosyal bilgiler eğitimi programlarında eleştirel düşünme becerilerine ne düzeyde yer verildiği araştırıldığı için durum çalışması deseni kullanılmıştır.

\section{Veri Toplama Araçları}

Araştırma veri toplama aracı olarak doküman incelemesinden yararlanılmıştır. Doküman incelemesine esas olarak sosyal bilgiler eğitimi lisans ve lisansüstü 
programları veri kaynağı olarak kabul edilmiştir. Çalışma kapsamında Yükseköğretim Kurulu tarafından üniversite listesinde yer alan 207 üniversitenin sosyal bilgiler lisansüstü eğitime yönelik ders katalogları, ders içerikleri ve AKTS bilgi paketleri ile 2018 yılında uygulamaya konulan Sosyal Bilgiler Öğretmenliği Lisans Programı incelenmiştir.

\section{Verilerin Analizi}

Çalışma kapsamında ulaşılan kaynaklar doküman incelemesi yoluyla sistematik bir şekilde analiz edilmiştir. Bowen'a (2009) göre elektronik belgeleri de incelemekte kullanılan doküman analizi, işlem adımlarına uygun olarak ulaşılan belgelerin değerlendirilmesi amacıyla kullanılır. Dokümanların analizi aşamasında betimsel analize başvurulmuştur.

Çalışma kapsamında ilk aşamada üniversite web siteleri üzerinde yapılan inceleme sonucunda sosyal bilgiler eğitimi tezli yüksek lisans ya da doktora programlarını sürdüren üniversiteler tespit edilmiştir. Sonrasında bu üniversitelerin ders katalogları, ders içerikleri ve AKTS bilgi paketleri çalışma dokümanları olarak kabul edilerek incelenmiş ve programda yer alan düşünme becerilerine odaklanan ya da bu becerilerle ilişkili olan dersleri tespit etmek amaçlanmıştır. Bu kapsamda öncelikle ders adları kontrol edilmiş ve içeriğinin düşünme becerilerini doğrudan ele aldığını şüpheye mahal vermeksizin ortaya koyan dersler "düşünme becerilerine odaklanan dersler" olarak kabul edilmiştir. Sonrasında ise içeriğinde düşünme becerilerine yer verilmiş olması muhtemel dersler belirlenerek ulaşılabilen ders içerikleri incelenmiş ve derslerin düşünme becerilerine en az üç hafta yer vermiş olması kriter olması kaydıyla şartları sağlayan dersler "düşünme becerileriyle ilişkili dersler" olarak nitelendirilmiştir. Bu nedenle farklı programlarda yer alan aynı ada sahip derslerin bir kısmı düşünme becerileriyle ilişkili sayılırken, bir kısmı içeriğinde düşünme becerilerine yer vermediğinden kapsam dişında tutulmuştur. Son olarak tespit edilen dersler arasından eleştirel düşünme becerilerini ele alan dersler belirlenmiştir. Aynı prosedür lisans programının incelenmesi aşamasında da kullanılmıştır.

\section{Bulgular}

Sosyal Bilgiler Eğitimi Lisansüstü Programlarında Eleştirel Düşünme ve Diğer Düşünme Becerileri

Türkiye'de bulunan 207 üniversitede yürütülen sosyal bilgiler lisansüstü eğitimine yönelik elde edilen bulgular Tablo 1'de sunulmuştur.

Tablo 1. Türkiye'de bulunan sosyal bilgiler eğitimi lisansüstü programları

\begin{tabular}{lcc}
\hline Program & f & \% \\
\hline Yüksek Lisans Programı & 28 & 13,53 \\
\hline
\end{tabular}




\begin{tabular}{lcc}
\hline Yüksek Lisans ve Doktora Programı & 23 & 11,11 \\
Lisansüstü Programı Bulunmayan & 156 & 75,36 \\
Toplam & 207 & $\% 100$ \\
\hline
\end{tabular}

Yükseköğretim Kurulu Başkanlığının internet sayfalarında 08.10.2021 tarihi itibarıla Türkiye'de toplam 207 üniversite bulunduğu belirtilmektedir. Çalışma kapsamında tüm üniversitelerin enstitü, AKTS bilgi paketi ve ders kataloglarına ilişkin internet adresleri incelenmiş ve 51 üniversitede sosyal bilgiler eğitimi tezli yüksek lisans programının eğitim ve öğretime devam ettiği, bu üniversitelerden 23'ünde ise doktora eğitiminin de sürdürüldüğü tespit edilmiştir. Türkiye'de bulunan üniversitelerin dörtte birinde sosyal bilgiler eğitimi üzerine lisansüstü programı bulunmaktadır.

Sosyal bilgiler lisansüstü eğitim yürütülen programların düşünme becerileri derslerine yer verme durumlarına ilişkin bulgular Tablo 2' de sunulmuştur.

Tablo 2. Bilgi paketinde düşünme becerilerine yönelik derslere yer verme durumlarına göre lisansüstü programlar

\begin{tabular}{lcc}
\hline Düşünme Dersi Bulunan Programlar & f & \% \\
\hline Sadece Doğrudan Düşünme Becerileri Dersi Bulunan Programlar & 1 & 1,96 \\
Sadece Düşünme Becerileriyle İlişkili Olan Dersler Barındıran & 11 & 21,57 \\
Programlar & & \\
Hem Düşünme Becerileri Hem de İlişkili Ders Bulunan Programlar & 9 & 17,65 \\
Düşünme Becerilerine Yönelik Ders Bulunmayan Programlar & 30 & 58,82 \\
Toplam & 51 & 100 \\
\hline
\end{tabular}

Üniversitelerin internet sitelerinde bulunan bilgi paketlerinin incelenmesi sonucunda sosyal bilgiler lisansüstü program yürütülen 51 üniversiteden sadece dokuzunda hem düşünme becerilerine doğrudan odaklanan hem de düşünme becerileri ile ilişkili dersler bulunmaktadır. Bir programda sadece düşünme becerilerini doğrudan odaklanan bir ders bulunurken, 11 programda ise düşünme becerileriyle ilişkili dersler bulunduğu anlaşılmıştır. Bu bağlamda doğrudan düşünme becerilerine yönelik derse sahip program sayısının toplam sosyal bilgiler lisansüstü program sayısına oranının dörtte bir civarında olduğu söylenebilir.

Bilgi paketlerinde tespit edilen derslerin sayılarına ilişkin bulgular Tablo 3'te sunulmuştur.

Tablo 3. Bilgi paketlerinde yer alan düşünme becerilerine yönelik toplam ders sayıları

\begin{tabular}{llll}
\hline Ders Türü & f & $\%$ \\
\hline
\end{tabular}




\begin{tabular}{lcc}
\hline Doğrudan Düşünme Becerilerine Yönelik & 13 & 28,89 \\
Düşünme Beceriyle İlişkili & 32 & 71,11 \\
Toplam & 45 & 100 \\
\hline
\end{tabular}

Ders katalogları ve bilgi paketlerinin incelenmesi sonucunda Türkiye'de sosyal bilgiler lisansüstü programlarında toplam 45 dersin düşünme becerileri ile doğrudan ya da dolaylı olarak ilişkili olduğu anlaşılmıştır. Bu derslerin 13'ü doğrudan düşünme becerilerini ele alırken geri kalan 32 ders ise bir şekilde düşünme becerileri ile ilişkisi kurulabilen derslerdir.

Bilgi paketlerinden elde edilen verilere göre programlarda düşünme becerilerine odaklanan derslerin listesi Tablo 4'te sunulmuştur.

Tablo 4. Düşünme becerilerine odaklanan derslerin listesi

\begin{tabular}{lc}
\hline Ders Adı & f \\
\hline Sosyal Bilgiler Eğitiminde Eleştirel ve Sorgulayıcı Düşünme Becerilerinin Öğretimi & 2 \\
Illköğretimde Eleştirel Düşünme Öğretimi & 1 \\
Sosyal Bilimlerde Eleştirel Düşünme & 1 \\
Sosyal Bilgiler Öğretiminde Yansıtıcı Düşünme & 1 \\
Sosyal Bilgiler Eğitiminde Argümantasyon Temelli Öğrenme & 1 \\
Sosyal Bilgiler Eğiminde Sorgulamaya Dayalı Öğrenme Yaklaşımı & 1 \\
Sosyal Bilgiler Eğitiminde Argümantasyon Temelli Bilim Öğrenme Yaklaşımı & 1 \\
Düşünme Becerileri Eğitimi & 2 \\
Sosyal Bilgiler Öğretiminde Düşünme Becerileri & 1 \\
İleri Düzey Düşünme Becerileri ve Öğretimi & 1 \\
Sosyal Bilimlerde Öğrenme ve Düşünce Gelişimi & 1 \\
\hline
\end{tabular}

Tabloda görüldüğü üzere düşünme becerilerine odaklanan derslerin üç tanesi doğrudan eleştirel düşünme becerilerini merkeze almaktadır. Tabloda bulunan derslerden dört tanesi ise eleştirel düşünme kapsamında sayılabilecek "yansitıcı düşünme, argümantasyon ve sorgulama" gibi becerilere ilişkindir. Kalan beş ders ise düşünme becerilerini bir bütün halinde ele alan içeriklere sahiptir.

Bilgi paketlerinden elde edilen verilere göre programlarda düşünme becerileriyle ilişkili derslerin listesi Tablo 5'te sunulmuştur.

Tablo 5. Düşünme becerileriyle ilişkili dersler listesi

\begin{tabular}{lc}
\hline Ders Adı & $\mathbf{f}$ \\
\hline Sosyal Bilgilerde Beceri Eğitimi (Çeşitli ders adları ile) & 13 \\
Medya Okuryazarlığı (Çeşitli ders adları ile) & 12 \\
\hline
\end{tabular}


Tablo incelendiğinde, düşünme becerilerine de içeriğinde yer veren derslerin büyük bir bölümünün medya okuryazarllğı ve sosyal bilgilerde beceri eğitimi başlığında toplandığı görülmektedir. Tabloda yer alan derslerin içeriğinin büyük bir bölümünün düşünme becerileri dışındaki konulara ayrıldığı, düşünme becerilerine ancak sinırlı bir süre ayrıldığı inceleme sonucu anlaşıldığından bu dersler düşünme becerileriyle ilişki dersler arasında sayılmıştır.

\section{Sosyal Bilgiler Eğitimi Lisans Programında Eleştirel Düşünme ve Diğer Düşünme Becerileri}

Programın incelenmesi sonucunda düşünme eğitimine odaklanan sadece tek bir dersin programda yer aldığı ve bu dersin de meslek bilgisi seçmeli ders statüsünde olduğu anlaşılmıştır. Bu ders Eleştirel ve Analitik Düşünme dersidir. Ders adından da anlaşılacağı üzere doğrudan eleştirel ve analitik düşünmeyi konu edinmektedir. Bu nedenle dersin, düşünme becerilerine odaklanan ders olduğu kabul edilmiştir.

Analiz sonucunda programda yer alan sadece bir dersin düşünme becerileriyle ilişkili olduğu anlaşılmıştır. Düşünme becerileriyle ilişkili olan "Medya Okuryazarlığ1 ve Eğitimi" dersi programda alan eğitimi zorunlu dersler arasında bulunmaktadır. Dersin içeriğinin incelenmesinde konu içeriğinin yanında düşünme becerilerine de vurgu yapıldığı anlaşıldığından dersin düşünme becerileriyle ilişkili ders olduğu kabul edilmiştir.

Hayat boyu öğrenme ile 21 YY. becerileri arasında literatürde sıklıkla ilişki kurulmuş olması nedeniyle programda yer alan Yetişkin Eğitimi ve Hayat Boyu Öğrenme dersinin düşünme becerileriyle ilişkili olabileceği düşünülmüştür. Ancak ders içeriği incelendiğinde dersin 21. Yüzyıl becerileri ile ilişkisinin kurulmadığı görülmektedir. Bu nedenle söz konusu dersin düşünme eğitimi ile ilişkili olmadığ kanısına varılmış ve kapsam dışı bırakılmıştır.

Programda yer alan derslerin tamamının içerikleri incelenmiş, herhangi bir hataya düşmemek bakımından programda "eleştirel, yaratıcı, biliş, düşünme, düşünce, beceri, sorgulama, analitik, üst düzey, üstbiliş" gibi düşünme becerilerini işaret etmesi olası anahtar kelimelerle aramalar gerçekleştirilmiş ancak düşünme becerilerini vurgulayan başkaca derse rastlanılmamıştır.

$\mathrm{Bu}$ bağlamda lisans programında öğrenim gören sosyal bilgiler öğretmen adaylarının öğrenimleri boyunca zorunlu olarak sadece bir tane düşünme becerileriyle ilişkisi kurulabilecek dersler karşılaştıkları, meslek bilgisi seçmeli derslerinden ise sadece bir tanesi kontenjan olduğu ve ders açldığ ulaşılmıştır. Bunun dışında sosyal bilgiler öğretmen adaylarının ancak öğretim 
üyelerinin açabilecekleri alan eğitimi seçmeli derslerde eleştirel düşünme gibi düşünme becerilerine odaklanan dersleri alabilecekleri anlaşılmaktadır.

\section{Sonuç ve Tartışma}

Ortaokul programlarında yer alan sosyal bilgiler dersi genel olarak istenilen özelliklere sahip vatandaş yetiştirme amacına yönelik hizmet vermektedir. Bu bağlamda İlkokul ve Ortaokul Sosyal Bilgiler Dersi Öğretim Programı, yetiştirilmek istenilen vatandaşın sahip olması gereken beceri ve değerleri içinde barındırmaktadır. Programda belirtilen becerileri öğrencilerin kazanması ise onlara rehberlik edecek öğretmenlerin bu becerilere sahip olması ve bu becerileri kullanmaya istekli olması ile mümkün olabilir. Düşünme becerileri de dâhil olmak üzere tüm beceriler ancak üzerinde pratik yapılarak geliştirilebilir. Bu becerilere aşina olmayan ve onları kullanmayan öğretmenlerin, kendi eğitim pratiklerine bu becerileri adapte etmeyecekleri açıktır. Bu nedenle vatandaş yetiştirme amacına ulaşmakta önemli rol üstlenen sosyal bilgiler öğretmenlerinin, bu becerileri de kapsayan eğitim yaşantılarını deneyimlemeleri önem arz etmektedir.

Sosyal bilgiler öğretmen adayları 2018 yılından itibaren Yükseköğretim Kurulu tarafından uygulamaya konulan Sosyal Bilgiler Öğretmenliği Lisans Programının belirlediği çerçeve dâhilinde öğretim görmektedir. Eleştirel düşünme becerileri de dâhil olmak üzere tüm becerilerin üzerinde çalışmak suretiyle geliştirilebileceği göz önünde bulundurulduğunda programın, adaylara düşünme becerilerini merkeze alan eğitim yaşantıları sunabilecek nitelikte olması gerektiği açıtır. Ancak lisans programının analiz edilmesi sonucunda programda eleştirel düşünme becerilerini doğrudan ele alan zorunlu bir dersin bulunmadığı, bu amaca dönük sadece bir adet meslek bilgisi seçmeli dersinin programda yer aldığı bulgusuna ulaşılmıştır. Bununla birlikte programda genel olarak düşünme becerilerine yönelik bir dersin de yer almadığı, sadece medya okuryazarlığı dersinde öğretim üyelerinin eleştirel düşünmeye, kendi tercihleri nispetinde odaklanabilecekleri anlaşılmıştır. Yine öğretim üyelerinin diğer derslerini düşünme becerilerini geliştirmeye olanak sağlayacak nitelikte yürütebilecekleri savunulabilir. Ancak bu kabul edildiğinde dahi eleştirel düşünmenin geliştirilmesi tesadüflere ve kişisel tercihlere bırakılmış olacaktır. Bu bağlamda Sosyal Bilgiler Öğretmenliği Lisans Programının eleştirel düşünme başta olmak üzere düşünme becerilerine önem vermediği düşünülmektedir. Hâlbuki bu program ile eğitim ve öğrenim gören adaylar mesleğe başladıklarında, eleştirel düşünmeye güçlü bir şekilde vurgu yapan Sosyal Bilgiler Dersi Öğretim Programını uygulamakla yükümlü olacaklardır.

Sosyal bilgiler eğitimi lisans programlarında öğrenim gören adayları, eğitim fakültelerinin sosyal bilgiler eğitimi anabilim dallarında görev yapan öğretim üyelerinin kılavuzluğunda yetişmektedir. Lisans programında eleştirel düşünmenin neredeyse yok sayılmış olması, sosyal bilgiler eğitimcilerinin bu becerilere dönük olarak derslerini yürütmeleri ile bir seviyeye kadar tolere edilebilir. Bu bağlamda 
sosyal bilgiler eğitimcilerini yetiştiren lisansüstü sosyal bilgiler eğitimi programlarının eleştirel düşünme becerilerini yeterli düzeyde ele alması gereklidir. Ancak çalışma kapsamında elde edilen bulgular lisansüstü programlarının da eleştirel düşünme becerilerini desteklemekten uzak olduklarını göstermektedir. Ülkemizde yürütülen toplam 51 sosyal bilgiler eğitimi lisansüstü programının sadece 21'inde düşünme becerileriyle bir şekilde ilişkili dersler bulunmaktadır. Doğrudan düşünme becerilerini odağa alan dersler kıstas olarak belirlendiğinde bu sayı 10'a düşmektedir. Bahse konu bu programlarda 13'ü doğrudan düşünme becerilerine odaklanan toplam 45 dersin düşünme becerilerine katkı sağlayabileceği düşünülmektedir. Gerek tezli yüksek lisans gerekse doktora programlarının seminer dersleri de dâhil olmak üzere en az sekizer dersten oluştuğu göz önünde bulundurulduğunda bir senede Türkiye çapında verilen olası 592 dersin sadece 13'ünün düşünme becerilerine doğrudan odaklandığı, 32 dersin ise öğretim üyesinin yaklaşımına bağlı olmak kaydıyla düşünme becerilerine katkı sağlayabileceği ortaya çımmaktadır. Bu ise sosyal bilgiler eğitimi lisansüstü programlarında verilen tüm derslerin yaklaşık \%2'sinin doğrudan düşünme becerilerine odaklandığını göstermektedir. Düşünme becerilerine doğrudan odaklanan 13 dersin ise sadece dört tanesinin bütün halinde eleştirel düşünmeyi, dört tanesinin ise eleştirel düşünme kapsamında bulunan becerileri kapsadığ dikkate alındığında lisansüstü programlarda da eleştirel düşünme becerilerine yeteri kadar önem verilmediği daha net anlaşılmaktadır. Bu bilgiler ışığında gerek lisans gerekse lisansüstü düzeyde uygulamaya konulan sosyal bilgiler eğitimi programlarında eleştirel düşünmenin göz ardı edildiği söylemek yerinde bir tespit olacaktır.

Araştırma bulguları lisans ve lisansüstü düzeyde sosyal bilgiler eğitimi üzerine eğitim ve öğretim faaliyetlerini sürdüren programların başta eleştirel düşünme olmak üzere düşünme becerilerine önem vermediğini ve görmezden geldiğini açıkça ortaya koymaktadır. Eleştirel düşünme becerilerinin geliştirilmesi, öğretmenlerin ve öğretmen eğitimcilerinin kişisel çabalarına ve tercihlerine bırakılmış durumdadır. Öğretmen ve öğretmen eğitimcilerinin eleştirel düşünme konusundaki yetkinlik ve yeterlikleri de tamamıla tesadüfi gelişmelere bırakılmıştır. Türkiye'de eğitimin tüm kademelerinde eleştirel düşünme becerileri konusunda başarı sağlanamadığını gösteren birçok çalışma bulunmaktadır (Acun, Demir ve Göz, 2010; Akar, 2007; Gülveren, 2007; İbrahimoğlu ve Öztürk, 2013; Öztürk ve Ulusoy, 2008; Yücel ve Köçer, 2018). Her kademede öğrenim gören öğrencilerin eleştirel düşünme becerilerini yeterli düzeyde geliştirememiş olması ve bu becerileri geliştirmekle sorumlu sosyal bilgiler öğretmen ve öğretmen eğitimcilerini yetiştiren programlarda da bu becerilerin göz ardı ediliyor olması birlikte değerlendirildiğinde Türkiye'nin sistematik bir şekilde eleştirel düşünen bireyler yetiştirmesi kolay görünmemektedir. Bu kısır döngüyü kırabilecek yegane unsur, sistemli bir eleştirel düşünme planına sahip olmaktır. Görüldüğü üzere Ortaokul Sosyal Bilgiler Ders Öğretim Programının amaçlarında ve becerilerinde eleştirel düşünmenin kazandırılacak bir beceri olarak belirtilmesi gerçek hayatta karşılığını bulmamaktadır. 
Düşünmeye dönük eğitim verilmediği takdirde bireylerin nitelikli düşünme becerileri tesadüfi gelişimlere teslim edilmiş olur. Modern dünyada bireylerden sorumluluk almaları, iyi ve adil kararlar vermeleri ve çözüm üretmeleri beklenmektedir. Bu niteliklere sahip bireylerin potansiyellerini uç noktalara kadar ulaştırabilmeleri için akıl yürütmeye ve düşünmeye dönük eğitim almaları gerekmektedir (Baker, Rudd ve Pomeroy, 2001). Etkin, hayata hazır ve toplumsal sorumluluklarından kaçmayan vatandaşlar için söz konusu bu düşünme becerileri bir ön koşul olarak kabul edilebilir. Küresel ekonomi, demokratik yaşam, hızla dönüşen ve karmaşık bir hale gelen toplum, mantıklı ve iyi kararlar verebilecek insanları gerektirir (Reed, 1998). İnsanlar geçmişten günümüze sabit prosedürler, alışkanlıklar ve belirli rutinlerle düşünmeye eğilimlidir (Paul ve Elder, 2002). Değişen ve karmaşıklaşan dünyada böylesi bir düşünme geleneği güncel sorunlar karşısında bireylerin hatalı düşünme ve davranma ihtimallerini yükseltmektedir. Bu durum göz önünde bulundurulduğunda düşünme becerileri üzerine bir eğitim zorunluluk kazanmaktadır. Artık durağan bir yapıda olmayan bilgi dinamik bir statü kazandığından, kişilerce bilgiler anlaşılmalı, anlamlandırılmalı, yorumlanmalı ve böylece yeniden var edilmelidir (Halpern, 2002). Bilginin mahiyetindeki değişme de düşünme eğitimini zorunlu kılan bir unsurdur. Eleştirel yaklaşımla birbirileriyle etkileşimde bulunan insanların toplamı anlamına gelen toplum (Case ve Wright, 1997), eleştirel düşünmeyi karar verme ile problem çözme süreçlerinde kullanan kişilerle mümkün olabilir. Ayrıca bu tür becerileri toplumsal sorunların ortadan kaldırılmasında kullanan bireyler demokratik toplumlar tarafindan istenilen vatandaşlardır (Seferoğlu ve Akbıyık, 2006). Bu nedenle eleştirel düşünme eğitimi toplumların demokratik dönüşümlerinde de önemli bir rol oynamaktadır.

Araştırma bulguları lisans ve lisansüstü sosyal bilgiler eğitiminde eleştirel düşünmenin öğretmen ve öğretmen eğitimcilerin tercihlerine bırakıldığını göstermektedir. Ancak eleştirel düşünme kişilerin tercihlerine bırakılacak kadar önemsiz bir seçenek değildir, aksine eleştirel düşünme modern toplumlar için bir zorunluluktur (Norris, 1985; Halpern, 2002). Bu bağlamda Türkiye'nin eğitimde kapsamlı bir eleştirel düşünme öğretimi planına ihtiyaç duyduğu düşünülmektedir.

\section{Etik Beyan}

“Sosyal Bilgiler Eğitimi Lisans ve Lisansüstü Programlarında Eleştirel Düşünme Becerileri" başlıklı çalışmanın yazım sürecinde bilimsel, etik ve alıntı kurallarına uyulmuş; toplanan veriler üzerinde herhangi bir tahrifat yapılmamış ve bu çalışma herhangi başka bir akademik yayın ortamına değerlendirme için gönderilmemiştir.

\section{Kaynaklar}

Acun, İ., Demir, M., \& Göz, N. L. (2010). Öğretmen adaylarının vatandaşlık yeterlilikleri ile eleştirel düşünme becerileri arasındaki ilişki. Sosyal Bilgiler Eğitimi Araştırmaları Dergisi, 1(1), 107-123. 
Akar, C. (2007). İlköğretim öğrencilerinde eleştirel düşünme becerileri. (Yayınlanmamış Doktora Tezi). Gazi Üniversitesi, Ankara.

Baker, M., Rudd, R., \& Pomeroy, C. (2001). Relationships between critical and creative thinking. Journal of Southern Agricultural Education Research, 51(1), 173-188.

Bowen, G. A. (2009). Document analysis as a qualitative research method. Qualitative Research Journal, 9(2), 27-40.

Case, R., \& Wright, I. (1997). Taking seriously the teaching of critical thinking. Canadian Social Studies, 32(1): 12.

Creswell, J. W. (2013). Araştırma Deseni: Nicel, nitel ve karma yöntem yaklaşımları (S. B. Demir, Çev Edt.). Ankara: Eğiten Kitap. (Orijinal çalışma basım tarihi 2012).

Durmaz, A., \& Kiriş Avaroğulları, A. (2016). Sosyal bilgiler derslerinde etkinlik uygulamalarının öğrenci motivasyonuna etkisi. Turkish Studies- International Periodical for the Languages, Literature and History of Turkish or Turkic, 11(3), 995-1010. http://dx.doi.org/10.7827/TurkishStudies.9409

Ennis, R. H. (1985). Goals for a critical thinking curriculum. In Developing minds: A resource book for teaching thinking (pp. 54-58). Association for Supervision and Curriculum Development.

Facione, P. A. (2015). Critical thinking: What it is and why it counts. https://www.researchgate.net/publication/251303244 Critical Thinking What It Is and Why It Counts

Facione, N. C., \& Facione, P. A. (1996). Externalizing the critical thinking in knowledge development and clinical judgment. Nursing Outlook, 44(3), 129-136.

Gülveren, H. (2007). Eğitim fakültesi öğrencilerinin eleştirel düşünme becerileri ve bu becerileri etkileyen eleştirel düşünme faktörleri. (Yayımlanmamış doktora tezi). Dokuz Eylül Üniversitesi, İzmir.

Halpern, D. F. (2002). Thought and knowledge: An introduction to critical thinking. Londra: Routledge.

İbrahimoğlu, Z., \& Öztürk, C. (2013). Sosyal bilgiler dersinden örnek olay yöntemi kullanımının öğrencilerin akademik başarı derse karşı tutum ve eleştirel düşünme becerileri üzerine etkileri. Uludă̆ Üniversitesi Eğitim Fakültesi Dergisi, 26(2), 523548.

Lipman M (1987). Critical thinking: What can it be? Analytic Teaching, 8(1), 5-12.

MEB. (2018). Illkokul ve ortaokul 4, 5, 6 ve 7. sinıflar sosyal bilgiler dersi öğretim programı.

Norris, S. P. (1985). Synthesis of research on critical thinking. Educational leadership, 42(8), 4045.

Öztürk, N., \& Ulusoy, H. (2008). Lisans ve yüksek lisans hemşirelik öğrencilerinin eleştirel düşünme düzeyleri ve eleştirel düşünmeyi etkileyen faktörler. Maltepe Üniversitesi Hemşirelik Bilim ve Sanatı Dergisi, 1(1), 15-25.

Paul, R., \& Elder, L. (2002). Critical thinking: Tools for taking charge of your professional and personal life. Financial Times Prentice Hall. 
Reed, J. H. (1998). Effect of a model for critical thinking on student achievement in primary source document analysis and interpretation, argumentative reasoning, critical thinking dispositions, and history content in a community college history course (Yayımlanmamış Doktora Tezi). University of South Florida, Florida.

Seferoğlu, S. S., \& Akbıyık, C. (2006). Eleştirel düşünme ve öğretimi. Hacettepe Üniversitesi Ĕ̆itim Fakültesi Dergisi, 30, 193-200.

Yin, R. K. (2009). Case study research, design and methods (4th ed.). Sage

Yücel, A. G., \& Köçer, M. (2018). Sosyal bilgiler öğretmen adaylarının eleştirel düşünme düzeylerinin gelişiminde tartışmalı konuların etkisi. Anemon Muş Alparslan Üniversitesi Sosyal Bilimler Dergisi, 7(3), $\quad$ 129-139. https://doi.org/10.18506/anemon.468137 